\title{
EQUITY AND INEQUITY OF CORPORATE TAXATION IN THE UNITED STATES.
}

\begin{abstract}
"Few questions are more important or have been more embarrassing than those arising from the efforts of a state or its municipalities to increase their revenues by exactions from corporations engaged in carrying on interstate commerce."

The above language is that of Mr. Justice Brewer in Atlantic and Pacific Telegraph Co. v. Philadelphia, Igo U. S. x60. Similar words might as well be said concerning the efforts exerted by the states to subject to taxation corporations generally, regardless of whether they are employed in interstate commerce. Some of these efforts have been praiseworthy, some not. It is the purpose of this article to discuss in a general way, the equitable and inequitable features of corporate taxation in this country and not to dwell at length on either the power of the state to tax the subjects, consisting of corporations and corporate interests, within its jurisdiction, or the state's power to impose double taxation on these subjects, in certain cases, which it undoubtedly may do unless restricted by constitutional provisions. ${ }^{1}$ It is the policy of some of the states as indicated by their statutes, or rather a lack of proper statutory provisions, that the writer wishes to discuss.

Corporations and corporate interests should, in justice. bear a just proportion of the burden of supporting the government that protects them, as well as private individuals. It has been the aim of the state legislatures during the past fifty years to enact appropriate legislation whereby these artificial bodies and their interests could be efficiently taxed.

Before the many complicated business inventions of the age, chiefly consisting of corporations, came into existence, and even at their inception, no special systems of subjecting these enterprises and their interests to taxation were generally in
\end{abstract}

I. Toll-Bridge Co. v. Osborn, 35 Conn. 7; U. S. Express Co.v. Ellyson, 28 Iowa 370; State v. Branin, 23 N. J. L. 484; State v. Newark, 25 N. J. L. 315; Rudderow v. State, 3I N. J. L. 512; Prairie Cattle Co. v. Williamson, 5 Okla. 488; Com. v. Fall Brook Coal Co., 156 Pa. St. 488. 
force. The legislatures did not and could not foresee the urgent necessity for the enactment of statutes broad enough to subject to taxation all the taxable elements and interests possessed by corporations. It was not long, however, before the fact was discovered that certain corporate interests could and should be placed in the category of taxable subjects. The courts recognized the equity and justice of the duty of corporations and corporate interests to contribute to the support oi the government by holding that corporations could be considered as "persons," 2 "individuals," 8 "inhabitants," 4 and as "owners" of property, ${ }^{5}$ within the meaning of the general tax laws subjecting to taxation generally the properties of persons, individuals, inhabitants, and owners of property, respectively. Realizing the inadequacy of the general tax laws to reach taxable corporate interests, the legislatures sought to devise special methods of subjecting these interests to the support of the public burdens, by passing legislation especially making corporations and corporate interests as a class subject to taxation. Different corporations were placed in different classes and certain of the classes thus created were subjected to different methods of assessment. This legislation was new and of course was strenuously contested as to its constitutionality, but it was upheld and is now in vogue.

Just as soon as a state devised a good legislative scheme whereby corporations and their interests could be effectually reached for the purposes of taxation, other states either adopted or attempted to make an improvement on it; so there has been a race during the past fifty years between the different states of

2. Cortis v. Kent Water Works Co., 7 B. \& C. 314; Trustees of Pineville Pub. Graded Schools v, Bell County Coke and Improvement Co., 96 Ky. 68; Louisville, etc., $R$. Co. v. Com., I Bush (Ky.) 250; Chicago, etc., $R$. Co. v. Ellson, I13 Mich. $30 ;$ British Com. L. Ins. Co. v. Com'rs, I Keyes (N. Y.) 303; Matter of Adler, 76 N. Y. App. Div. 57I; Miller v. Com., 27 Gratt. (Va.) Iro. See also People v. McLean, 8o N. Y. 254; Peoplev. Tax Com'rs, 23 N. Y. 242.

3. Bank of United States v. State, I2 Smed. \& M. (Miss.) 456.

4. Trustees of Pineville Pub. Graded Schools v. Bell County Coke and Improvement Co., $96 \mathrm{Ky}$. 68; Baldwin v. Trustees of Ministerial Fund, 37 Me. 369; Tripp v. Merchants' Mut. F. Ins. Co., I2 R. I. 435; Ontario Bank v. Bunnell, ro Wend. (N. Y.) r86. But see Hartfort F. Ins. Co. v. Hartford, 3 Conn. I5; Savings Bank of New London v. New London, 20 Conn. IIr; Cherokee Ins., etc., Co. v. Justices of Whitfield County, 28 Ga. I2r.

5. Savings Bank of Newi London v. New London, 20 Conn. Irr. 
the Union, to see which one of them could the most effectually subject the corporations and corporate interests within its borders to the payments of taxes. This has been especially noticeable concerning interstate corporations. New properties and elements of taxable value were discovered or were naturally worked out in the course of time. As a result we have a number of vulnerable points where a corporation and its interests may be successfully attacked by the exercise of the state's taxing power.

It has been judicially declared that corporations may possess the four following elements of taxable value: Franchises, capital stock in the hands of the corporation, shares of the capital stock in the hands of individual stockholders, and corporate property. ${ }^{6}$ Each of these elements, under certain circumstances, may be an appropriate subject of taxation.

It is of the greatest importance to distinguish the element taxed from the means employed to measure the tax. ${ }^{7}$ Often it is the case that taxes denominated as dividend and capital stock taxes, taxes on earnings and gross receipts, are franchise taxes pure and simple, but measured by dividends, capital stock. earnings or gross receipts, as the case may be. A franchise tax may be an arbitrary sum demanded of the corporation to be paid at certain periods, or it may be a sum determined by one of the enumerated means of measuring the tax, such as a tax on dividends or gross receipts as above stated, in which cases the method of measurement fixes the tax. Franchise taxes are usually collected from the corporation as such, but the legislature has the power to provide that the lessee of a railroad shall pay the tax and deduct the same from the rent to be paid. ${ }^{8}$

Let us now consider what some of the states have actually done and attempted to do in reference to taxing corporations.

6. Tennessee v. Whitworth, II7 U. S. x29.

7. Provident Inst. v. Massachusetts, 6 Wall. (U.S.) 6rx; Society for Savings v. Coite, 6 Wall. (U. S.) 594; Hamilton Co. v. Massachusetts, 6 Wall. (U. S.) 632; Home Ins. Co. v. New York, 134 U. S. 594; Phoenix Carpet Co. v. State, II8 Ala. I43; State v. Stonewvall Ins. Co., 89 Ala. 335; State v. Maine Cent. R. Co., 74 Me. 376; State v. United States Fidelity, etc., Co., 93 Md. 314; Cumberland, etc., $R$. Co. v. State, 92 Md. 668; State v. Philadelphia, etc., R. Co., 45 Md. 36I; Standard Underground Cable Co.v. Atty.-Gen., 46 N. J. Eq. 270; Marsden Co. v. State Board of Assessors, 61 N. J. L. 46r; People v. Home Ins. Co., 92 N. Y. 328; Kittanning Coal Co. v. Com., 79 Pa. St. Ioo; Philadelphia Contributionship etc. v. Com., $98 \mathrm{~Pa}$. St. 48; Com. v. New York, etc., R. Co., I50 Pa. St. 234; State v. Bradford Sav. Bank, etc., Co., 7I Vt. 234.

8. Vermont, etc., R. Co. v. Vermont Cent. R. Co., $63 \mathrm{Vt}$. r. 
It has been the practice of many of the states for a long time to require corporations to pay a tax levied upon the shareholders. It is the common, if not the only mode of taxing shareholders in many states, and in several of them the portion of this tax that properly should go as the shareholder's contribution to local or municipal taxation is thus collected by the state from the corporation and paid over to the local municipal authorities. Where there are shareholders not residing in the state, this mode of taxation is the only way in which the state can reach their shares for taxation.

Some of the states of the Union have exhibited more activity than others in reference to corporate taxation. From an examination of the laws passed by the different states it is apparent that few states have exhibited such alertness and have exercised their powers to such a searching extent in reference to corporate taxation as Pennsylvania. Pennsylvania has progressed in the administration of governmental functions and the lawmaking power has kept pace with the many business inventions of the age, compelling them to contribute their just proportion to the support of the government that affords them protection in the carrying on of their business enterprises. This state has contributed much to the law of corporate taxation as it exists to-day. It was the pioneer state in enacting certain legislation concerning the taxation of great interstate railroads, and its legislation was among the first of its kind to be considered and upheld by the Supreme Court of the United States. Recognizing that corporations of enormous wealth should, in justice, contribute to the support of the government as well as individuals, Pennsylvania under successive statutes enacted in $x 868, x 874,1877$ and 1879, adopted a mode to ascertain the proportion of a railroad company's property that should be taxed in the state. This was done by taking as a basis of assessment such proportion of the capital stock of the company as the number of miles over which the railroad ran its cars within the state, bore to the whole number of miles, in that and other states, over which its cars were run. Concerning this method of assessment, the Supreme Court of the United States said, "This was a just and equitable method of assessment; and, if it were adopted by all the states throigh which these carsran, the company would be assessed upon the whole value of its capital stock, and no more." 9

In 1868 Pennsylvania passed an act that subjected to taxa-

9. Pullman's Palace Car Co. v. Pennsylvania, I4I U. S. I8. 
tion the interest on foreign-held corporate bonds. This statute was presented to the Supreme Court of the United States for consideration and in 1872 that court decided that the statute was unconstitutional. This decision, resulting from Pennsylvania legislation, has had a far-reaching effect and is one of the greatest decisions of the highest court of our land concerning the subject of taxation and the place where property may be taxed. ${ }^{10}$

Under an act passed in 1885 and amended in I89r, Pennsylvania provided for the taxation of resident bond holders of private corporations, and made it the duty of the corporation to assess and collect the tax for the state. This statute has many times been upheld and construed by the Supreme Court of Pennsylvania and may serve as a model for similar statutes to be enacted by other states of the Union. The tax levied under this act is not in any sense or in any degree a tax against the corporation or its property, but it is levied upon the individual citizen of the state who holds the bonds. The corporation is chargeable with the tax only as a collector. The tax is not against the bond holders generally. Only the bond holders that are within the taxing power of the state are liable. ${ }^{11}$

Next to Pennsylvania, Illinois may be said to occupy a position of prominence in reference to the enactment of legislation concerning the taxation of artificial bodies, especially railroad corporations. One of the methods of taxing a railroad is by subjecting it to fragmentary assessments by the numerous subdivisions of the state through which the railroad runs, but because of the peculiar nature of railroad property, its dissimilarity in use and value to the mass of other property, and its continuous extent through different localities, it is commonly regarded by the states that it cannot, in justice to the owners, be as fairly and uniformly valued by the numerous local instrumentalities provided for assessing other property, as by a state board created for the purpose. The statutes of a large number of the states show that the practice of assessing railroads as units by state boards is very general.

The act of the Legislature of Illinois, passed March $3^{\circ}, 1872$, made provision for the taxation of railroads and other corporations, the main feature of which was the leaving to each county, city and town, the power of assessing for taxation what was properly local in the same manner that other similar property

Io. State Tax on Foreign-held Bonds, I5 Wall. (U. S.) 300.

I1. Com. v. Lehigh Valley R. Co., I86 Pa. St. 235. 
was taxed in that municipality, and at the same time to subject to like taxation on some fair basis that which was not in its nature so clearly local, but which, by reason of its being appurtenant or incident to the railroad, should pay its share to the state, and to all the counties, towns and cities through which any part of the road ran. The theory of the system was to treat the railroad track, its rolling stock, its franchise, and its capital, as a unit for taxation, and to distribute the assessed value of this unit according as the length of the road in each county, city and town compared to the whole length of the road. The Supreme Court of the United States held that this method of assessment was neither in conflict with the constitution of Illinois, nor inequitable. ${ }^{12}$

Having considered the justice and equity of forcing corporations and corporate interests to contribute to the support of the government, let us now see whether the state legislatures have been as fair to the subjects of taxation as they have been just to their respective states. Some states are not getting enough from corporations, some are getting too much. We hear a great deal about proposed reforms in the laws relating to marriage and divorce. Many of the states have experienced a reform in their laws pertaining to negotiable instruments. It is not always the case, however, that the necessity for a reform grows out of the evils existing in laws concerning domestic relations, or transactions of a commercial nature between private parties. Reforms may sometimes be necessary in matters that directly touch the state, where the evil sought to be remedied is one that exists between the state and the subject rather than between the subjects themselves. This may arise from evils and injustices of the criminal laws, but in cases where criminal statutes unjustly work a hardship and are contrary to the spirit and the necessities of the times, popular disfavor may act as a restraint on the enforcement of such laws. However, this situation does not arise in reference to inequitable laws working an unjust imposition of taxes. If there is any reform sorely needed in any branch of the law, surely the laws of some of the states should undergo a radical change in reference to taxation, especially the taxation of corporations and corporate interests. The labors of the American Bar Association could be spent in no better way than to worl in the interest of devising better systems of raising money for the sup-

I2. State Railroad Tax Cases, 92 U. S. 575. 
port of the state governments. Quite a number of the states have enacted laws which tend to avoid unjust and double taxa. tion, but there still exists plenty of room for further progress in this line, especially where the same property owned by the same person is subjected to taxation in more than one jurisdiction. In such cases, a uniform system of taxation is needed, as much as was needed a uniform negotiable-instruments law.

Even though a corporation possesses no soul and is devoid of suffering mental anguish, yet it should not be forgotten that a business enterprise of this kind is composed of citizens who are entitled to equality and justice before the law the same as other citizens. The fact that a citizen's capital is invested in a corporation or its property does not warrant an unjust imposition of taxes upon such capital, different from that imposed upon other property. In many cases an unfriendly feeling has caused corporations to suffer hardship in contributing to the public burdens. Let us take under consideration some of the situations wherein corporations and certain corporate interests are subjected to unfair, but not necessarily illegal taxation.

The burden of taxation may be unfair in the following cases:

First. Where the stockholders of a corporation are taxed on their shares of stock in the state where they dwell and are also taxed on the same shares by another state wherein the corporation is located. Such a tax was sustained by the Supreme Court of Rhode Island in a case where a shareholder contested his liability to taxation in Rhode Island, the state of his resi. dence, on stock which he held in certain corporations formed and operating under the laws of Massachusetts, in which state the stockholder had aiready paid taxes on the same stock. The court said, "The plea avers that the defendant has already paid a tax assessed upon the shares in Massachusetts. It is doubtless a hardship for him to pay taxes on the property in two states. But the Massachusetts tax, even if valid, could not divest this state of its jurisdiction. The laws of Rhode Island are paramount in Rhode Island, and all the inhabitants of the state are subject to them without regard to the laws of any other state. * * * It would certainly be going too far to hold that a man of wealth, living in Rloode Island, cannot be taxed at all in Rhode Island, if his property is all invested in the stocks of a manufacturing corporation of another state, and there subject to taxation." 13

I3. Dyer v. Osborne, II R. I. 321, 23 Am. Rep. 460. See also Worth v. Ash County, go N. Car. 40g, wherein the Rhode Island case is approved. 
In many jurisdictions statutory provisions have been enacted relieving from taxation shares of stock in foreign corporations held by residents, when the shares are taxed in the state where the corporation is located.

Second. Where the corporation is taxed on its capital stock or property and the shareholders are also taxed on their shares in the same state, there may be an injustice worked. The taxation of the capital stock or property and also the shares of stock, is generally upheld throughout the states of the Union, on the ground that the shares of stock and the capital stock or property are distinct properties belonging to different owners. But this technical legal reasoning does not change the result, which amounts to an unfair burden being imposed on the shareholders who are already taxed on their shares of stock. It is undeniable that in such cases the shareholders bear the burden of the tax imposed on the corporation, inasmuch as the shareholders constitute the corporation and indirectly own its property. ${ }^{14}$

In a case recently decided by the Supreme Court of Michigan concerning the taxation of shares of stock when the corporation is taxed on its capital stock or property, the court said, "We are aware that many courts have held that such laws do not require double taxation, upon the very technical reasoning that the tax is not levied upon the same property, and that it is not imposed upon the same person; both of which propositions are true in a sense, but are also untrue in another substantial sense, as stockholders are likely to learn if the action of the authorities in the case is sustained. So, several of the text-books assert that the weight of authority sustains the rule that the states may impose taxes upon both corporation and stockholder, though, without exception, they admit the severity and injustice of such measures, and say that the courts will never permit it where the law is susceptible of another construction. This practice is so palpably unjust that Michigan does not tax shareholders in domestic corporations, where the property of the corporation is taxed." 15

Third. Another situation, that is similar in result to the second, is where the shareholders of a corporation are taxed in the state where they dwell and the corporation is also taxed on its property or capital stock in another state where it is located.

14. See Stroh v. Detroit, r3I Mich. rog.

15. Stroh v. Detroit, I3I Mich. Iog. 
This form of taxation has been deemed unjust, and many of the states pursue the more equitable policy of relieving from taxation domestic shares of stock in foreign corporations, where the corporations are taxed on their capital stock or property in another jurisdiction.

All of the above situations again and again have been presented to the courts for relief, but however unjust, the taxation has been upheld in the absence of legislative relief, on the grounds that the properties and owners are distinct, and that the protection afforded by the law should be supported by the property protected. Nevetheless, in many cases, the courts have reluctantly sanctioned such taxation and have stated that they were powerless to grant relief as the remedy was within the legislative domain, to which the aggrieved parties were directed.

Xenophon $P$. Huddy. 